\title{
Hva var det som skjedde?
}

Tider kommer, tider går - så også med ord og uttrykk.

Jeg er en ivrig leser av ordbøker, men det er nok første gang en ordbok har fått meg til å skoggerle. Skoggerle? Ja visst, ordet har fått plass i Nostalgisk ordbok, som er en samling av ord med nostalgisk klang. Boken er skrevet av Petter Schjerven, kjent fra TV-seriene Typisk norsk og

Tingenes tilstand.

\section{En uordinær ordsamling}

En ordbok er vanligvis et autoritativt oppslagsverk. Det er denne ikke. Tvert om, den er subjektiv både i utvalg og forklaringer. Se bare hvordan «bidé» utlegges: «liten vaskekum for underliv og føtter, setebadekar. Hva skjedde? Hvem lurte alle? Hvorfor er det bidé i alle bad innredet før 1980 ? Var anusvask så vanlig på den tiden? Nå står de der ubrukte og tørre - og fulle av ting man ikke har plass til noe annet sted på badet.»

Medisinere vil kanskje stusse over at f.eks. podagra og whiplash er tatt med, men i Schjervens univers gir det mening. Prosjektet er godt gjennomført - selv omslaget er en etterlikning av den klassiske serien Gyldendals blå ordbøker. Ideen om å trekke frem nostalgiske ord og uttrykk er imid- lertid langt fra ny. I f.eks. TV-serien Lille lørdag i midten av 1990-årene drev Harald Eia og Bård Tufte Johansen herlig harselas med ord som teleks, flanellograf og fogd. Utrydningstruede ord, som opprinnelig kom i to bind, er en annen tilnærming til det samme $(1,2)$.

\section{Hva de gamle vet}

Oftest er det i samtale med andre generasjoner at vi blir klar over ord som tiden har herjet med. I studietiden lærte vi at urinen ved hemolytiske anemier kunne bli bokkølfarget. Da læreren innså at mange av oss ikke hadde noe forhold til bokkøl (ja, det er oppslagsord i Nostalgisk ordbok), oppdaterte han teksten til noe ingen kunne ta feil av: colafarget urin.

\section{Erlend Hem}

erlend.hem@medisin.uio.no

Tidsskriftet

\section{Litteratur}

1. Skår A. Utrydningstruede ord. Samleutgave. Oslo: Messel forlag. 2008

2. Nylund MF. Ord på vei ut? Tidsskr Nor Legeforen 2008; 128: 731.

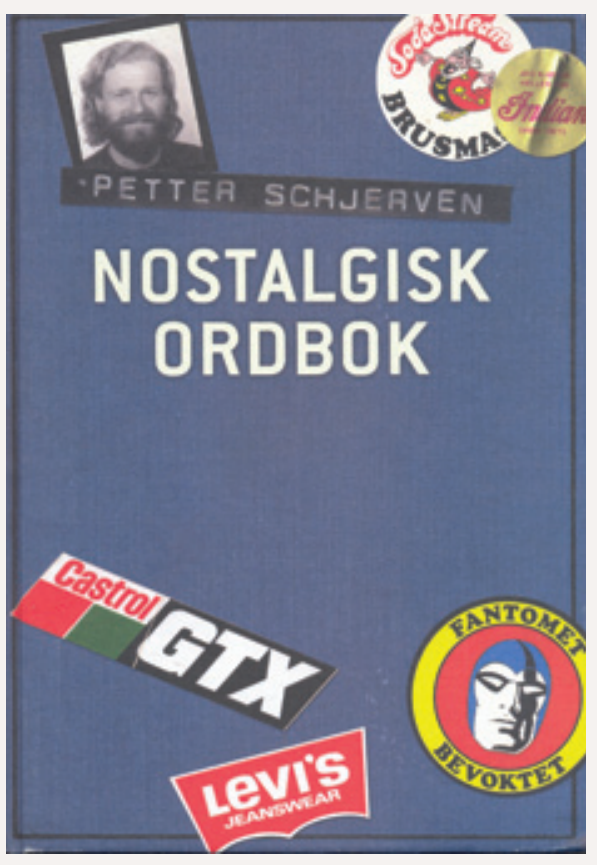

Petter Schjerven Nostalgisk ordbok 328 s, ill. Oslo: Vega forlag, 2010. Pris NOK 399

ISBN 978-82-8211-108-9 